\title{
Firm productivity and export markets: a non-parametric approach
}

\author{
Miguel A. Delgado ${ }^{\mathrm{a}, *}$, Jose C. Fariñas ${ }^{\mathrm{b}}$, Sonia Ruano ${ }^{\mathrm{c}}$ \\ ${ }^{a}$ Universidad Carlos III de Madrid, Departomento de Econometría, C./Madrid 126-128, \\ 28903 Getafe, Madrid, Spain \\ ${ }^{\mathrm{b}}$ Universidad Complutense de Madrid; Facultad de Ciencias Económicas, \\ Departomento de Economía Aplicada II, Madrid 28223, Spain \\ ${ }^{\mathrm{c}}$ Universidad Carlos III de Madrid and Banco de España, C./Madrid 126-128, Getafe, \\ Madrid 28903, Spain
}

Received 18 January 2000; received in revised form 30 January 2001; accepted 25 June 2001

\begin{abstract}
This paper examines total factor productivity differences between exporting and nonexporting firms These differences are documented on the basis of a sample of Spanish manufacturing firm over the period 1991-1996. The paper also examines two complementary explanations for the greater productivity of exporting firms (1) the market selection hypothesis, and (2) the learning hypothesis. Non-parametric tests are proposed and implemented for testing these hypotheses. Results indicate clearly higher levels of productivity for exporting firm than for non-exporting firms With respect to the relative merits of the selection and the learning hypotheses, we fin evidence supporting the self-selection of more productive firm in the export market. The evidence in favor of learning-by-exporting is rather weak, and limited to younger exporters.
\end{abstract}

Keywords: Total factor productivity; Exports; Stochastic dominance; Non-parametric tests

JEL classification: D24; F10; M20; L10

*Corresponding author Tel : + 34-916-24-9804; fax: + 34-916-24-9849

E-mail address: delgado@est-econ uc3m es (M A Delgado) 


\section{Introduction}

The link between efficienc and exports is one of the many features which the literature concerning productivity growth has focused on. A widespread and robust findin supported by this literature is the existence of significan differences in productivity among firms Furthermore, it has also been observed that these differences persist (see Griliches and Regev, 1995, and many others; for a review article see Tybout, 1997). One of the firms characteristics that contributes to this observed heterogeneity is the entry of firm into the export market. Studies by Aw and Hwang (1995), Bernard and Jensen (1995), Jensen and Wagner (1997), Aw et al. (1997), Clerides et al. (1998) and Aw et al. (2000), provide evidence on the fact that export-oriented firm are closer to the efficienc frontier than nonexporters.

The purpose of this paper is to measure total factor productivity differences between exporting and non-exporting firms First, the paper documents these productivity differences on the basis of a panel sample of Spanish manufacturing firm over the period 1991-1996. Therefore, we contribute to the growing body of empirical literature that examines the relationship between productivity and exports, adding another national perspective to the available evidence. The proposed methodological approach is the second contribution of the paper. We compare the entire distribution of productivities rather than just marginal moments. In particular, we compare the cumulative distribution functions of total factor productivity for different groups of firms exporters, non-exporters, entering exporters and exiting exporters. These distributions are ranked using the concept of stochastic dominance, and their differences are formally tested using Kolmogorov-Smirnov one and two-sided tests, which are consistent in the direction of general non-parametric alternatives. Third, the paper makes an attempt at sorting out the selection versus the learning explanations for the superior productivity of exporting firms The paper explores and tests for these two different, but non-mutually exclusive explanations by comparing productivity levels as well as productivity growth for groups of firm with different trajectories between the export and domestic markets.

Our empirical finding confir higher levels of productivity for exporting firm versus non-exporting firms With respect to the relative merits of the selection and the learning hypotheses proposed to explain the greater productivity of exporters, we fin evidence supporting the self-selection of more productive firm into the export market. The evidence in favor of the learning-by-exporting hypothesis is rather weak, and limited to younger exporters. These results are very much in line with those reported by Clerides et al. (1998), Bernard and Jensen (1999), and Aw et al. (2000). Although the methodology used differs throughout their research, they all come to a similar conclusion: market selection rather than learning-byexporting is the factor that leads to higher productivity of exporting firm with respect to non-exporting firms 
The rest of the paper is organized as follows. Section 2 summarizes the analytical arguments for the observed link between productivity and exports, and presents the testing procedures that have been used throughout the paper. Section 3 describes the data set, the index used for measuring total factor productivity and some general estimation issues. Section 4 reports the main empirical results. Conclusions are placed in Section 5.

\section{Analytical framework}

\subsection{Productivity differentials and exports}

To explain why exporters are more efficien than non-exporters, the analytical literature on productivity has outlined two arguments: (1) firm participating in international markets are exposed to more intensive competition; and (2) exporters have higher sunk entry costs than domestic firms Both explanations share the idea that export markets select the most efficien firm among the set of potential entrants into the export market. The firs argument is present in the literature concerning development economics and relies on the idea that product market competition in export markets is greater than competition in domestic markets and, therefore, affords fewer opportunities for inefficien firm (see Aw and Hwang, 1995, for further details on these arguments.) Empirical studies on trade reform (see Feenstra, 1997, for a survey) confir the existence of a positive relationship between competition and productivity.

The second argument to the explanation of superior productivity of exporting firm comes from models of industry dynamics by Jovanovic (1982), Hopenhayn (1992) and Ericson and Pakes (1995). These models predict the existence of a systematic relationship between patterns of entry and exit and productivity differences at the fir level. As Aw et al. (1997) argue, a similar statement applies to the relationship between export markets and productivity. Even if we consider that the competitive pressure in the domestic market and the export market is similar, differences in sunk entry costs can explain productivity differences between exporters and domestic-oriented firms The basic assumption underlying this argument is that a non-exporter must incur a sunk entry cost in order to enter the export market. Recent studies confir this assumption empirically: Roberts and Tybout (1997) fin that firm' previous export status is an important determinant of the decision to export and they interpret this as a favorable evidence to the existence of sunk entry costs in the export market. In particular, Campa (1998) find that exporting sunk entry costs are important for Spanish manufacturing firms

Models of industry dynamics have two consequences for the analysis of productivity differences between exporting and non-exporting firms First, higher entry costs for firm entering the export market with respect to those firm selling 
in the domestic market imply higher productivity levels for exporting firms Second, patterns of entry and exit in the export market are related to productivity differences at the fir level. On one hand, the productivity distribution of continuing exporters should stochastically dominate the distribution of entering and exiting exporters. On the other hand, entering exporters should have higher initial productivity relative to firm that remain outside of the export market.

The two outlined arguments are consistent with the hypothesis of selection. A third argument, not mutually exclusive with respect to the two previous ones, is based on the idea of exporting as a learning mechanism that allows firm to improve their productivity. The management literature describing the internationalization process either as a sequence of stages for the fir or as an innovation for the firm has emphasized the notion of exporting as a learning process.

To organize our empirical work we rely on the previous arguments, which suggest the following hypotheses be tested based on the concept of stochastic dominance:

(i) If productivity differences reflec selection and/or learning forces at work in export markets, the productivity distribution of exporting firm should dominate the productivity distribution of non-exporting firms

(ii) Self-selection implies that differences between exporting and non-exporting firm precede their entry in the export market. Therefore, in the period prior to their entry, the productivity distribution of entering exporters should dominate the productivity distribution of non-exporters.

(iii) Selection on the exit side of the market implies that the productivity distribution of continuing exporters should dominate the distribution of exiting exporters.

(iv) Finally, if the empirical consequences of learning-by-exporting are considered as well, differences between productivity levels for exporting and nonexporting firm should increase after the entry of exporters in the export market. Therefore, the productivity growth distribution of entering exporters should dominate the distribution of non-exporting firms

In the next section we describe a testing procedure for examining productivity differentials between groups of firm with different trajectories between the domestic and the export market.

\subsection{Testing procedure}

This section develops a procedure for comparing the productivity distributions of different groups of firms The panel structure of the sample of firm allows a classificatio of firm according to their trajectories between the export and the domestic market over a given period. We have designed different tests to explore whether or not transitions from domestic to export markets are consistent with firms productivity differences summarized in Section 2.1. 
Most of the empirical questions we are interested in can be formulated as comparisons between the distributions of fir productivity level or fir productivity growth corresponding to different groups in the population. Our procedure for testing differences between distribution functions relies on the concept of firs order stochastic dominance and permits us to establish a ranking for the compared distributions. Let $F$ and $G$ denote the cumulative distribution functions of productivity corresponding to two groups of firm that have to be compared, then (firs order) stochastic dominance of $F$ relative to $G$ is define by the following condition: $F(z)-G(z) \leq 0$ uniformly in $z \in \mathbb{R}$, with strict inequality for some $z$.

Let $Z_{1}, \ldots, Z_{n}$, be a random sample of size $n$, which corresponds to a group of firms from the distribution function $F$, and let $Z_{n+1}, \ldots, Z_{n+m}$, denote a random sample of size $m$, independent of the firs one, which corresponds to a different group of firms from the distribution function $G$; where $Z_{i}$ represents either the productivity level or the productivity growth of fir $i$. We are interested in testing the following hypotheses:

(i) Two sided test

$$
H_{0}: F(z)-G(z)=0 \text { all } z \in \mathbb{R} \quad \text { vs. } \quad H_{1}: F(z)-G(z) \neq 0 \text { some } z \in \mathbb{R}
$$

can be rejected.

(ii) One-sided test

$$
H_{0}: F(z)-G(z) \leq 0 \text { all } z \in \mathbb{R} \quad \text { vs. } \quad H_{1}: F(z)-G(z)>0 \text { some } z \in \mathbb{R}
$$

cannot be rejected.

One and two-sided test can also be formulated as

$$
H_{0}: \sup _{z \in \mathbb{R}}|F(z)-G(z)|=0 \quad \text { vs. } \quad H_{1}: \sup _{z \in \mathbb{R}}|F(z)-G(z)| \neq 0
$$

and

$$
H_{0}: \sup _{z \in \mathbb{R}}\{F(z)-G(z)\}=0 \quad \text { vs. } \quad H_{1}: \sup _{z \in \mathbb{R}}\{F(z)-G(z)\}>0,
$$

respectively. To give a more intuitive explanation let us suppose that $F$ and $G$ represent the productivity distributions for exporters and non-exporters, respectively. On one hand, the two-sided test allows us to determine whether both distributions are identical or not. On the other hand, the one-sided test permits us to determine whether or not a distribution dominates the other. Particularly, when the two-sided test is rejected and the one-sided test cannot be rejected, it indicates that $F$ is to the right of $G$. In other words, it implies that exporters' productivity distribution stochastically dominates non-exporters' productivity distribution.

The Kolmogorov-Smirnov test statistics for these one and two-sided tests are

$$
\delta_{N}=\sqrt{\frac{n \cdot m}{N}} \max _{1 \leq i \leq N}\left|T_{N}\left(Z_{i}\right)\right|
$$

and 


$$
\eta_{N}=\sqrt{\frac{n \cdot m}{N}} \max _{1 \leq i \leq N}\left\{T_{N}\left(Z_{i}\right)\right\},
$$

respectively, where $T_{N}\left(Z_{i}\right)=F_{n}\left(Z_{i}\right)-G_{m}\left(Z_{i}\right)$ and $N=n+m . F_{n}$ and $G_{m}$ represent the empirical distribution functions for $F$ and $G$, respectively. The limiting distributions of both test statistics, $\delta_{N}$ and $\eta_{N}$, are known under independence ${ }^{1}$.

\section{Measurement and estimation issues}

\subsection{The data}

The data set considered in this study is drawn from the 'Encuesta sobre Estrategias Empresariales' (ESEE), an annual survey which refers to a representative sample of Spanish manufacturing firms A firs characteristic of the data set is that, in the base year, firm were chosen according to a selective sampling scheme with different probabilities of fir participation depending on their size category. All firm with more than 200 employees (large firm ) were asked to participate, and the rate of participation reached approximately $70 \%$ of the population of firm within that size category. Firms that employed between 10 and 200 employees (small firm ) were chosen according to a random sampling scheme, and the rate of participation was close to $5 \%$ of the number of firm in the population. The same selection scheme was applied to every industry. Therefore, the coverage of the data set is different depending on the size group of firms Consequently, given the procedure used to incorporate firm into the survey, the characteristics of the distribution of Spanish manufacturing firms for given size groups and industries, can be estimated from our sample.

A second characteristic of the data set is that in subsequent years the initial sample properties have been maintained. On one hand, newly created firm have been added annually with the same sampling criteria as in the base year (see Ministry of Industry, 1992, for technical details.) On the other hand, exiting firm have been recorded in the sample of firm surveyed each year. Therefore, due to this entry and exit process, the data set is an unbalanced panel of firms

Over the period 1991-1996, the data set has collected 10,595 observations at the fir level that correspond to an average number of 1766 firm throughout the entire period. The yearly average distribution of firm can be classified for descriptive purposes, into fiv groups according to their export participation along the time period: exporters, non-exporters, entering exporters, exiting exporters and

\footnotetext{
${ }^{1}$ These test statistics were proposed by Smirnov (1939). Kolmogorov (1933) and Smirnov (1939) showed that, under the assumption that all the observations are independent, the limiting distributions of $\delta_{N}$ and $\eta_{N}$ under $H_{0}$ are given by $\lim _{N \rightarrow \infty} P\left(\delta_{N}>v\right)=-2 \Sigma_{k=1}^{\infty}(-1)^{k} \exp \left(-2 k^{2} v^{2}\right)$ and $\lim _{N \rightarrow \infty}$ $P\left(\eta_{N}>v\right)=\exp \left(-2 v^{2}\right)$, respectively. For more details see Darling (1957).
} 
switchers. For the firs two groups - firm that export every year and firm that do not export along the time period - figure indicate that there is a positive relationship between the size of firm and their participation in the export market: $78 \%$ of large firm export regularly while the rate of participation for small firm is $27 \%$. Firm turnover with respect to the export market corresponds to the group of entering exporters - firm becoming exporters during the period without further changes in the rest of the period - and to the group of exiting exporters - firm ceasing to export and not reswitching. Two features should be noted. First, the fraction of firm entering and exiting the export market implies a high turnover rate. The annual average rate for small firm is 16 and $11 \%$ for large firms Second, during the period the average entry rate is higher than the average exit rate. This difference suggests that the large increase in Spanish exports during the nineties has been partly due to a net increase in the number of exporting firms Finally, the group of switchers - firm that change their export status more than once during the period - represents 11 and $6 \%$ for small and large firms respectively.

\subsection{The measurement of firm productivity}

This section presents an index for measuring fir productivity that follows the framework developed in Aw et al. (2000). The index is an extension of the multilateral total factor productivity index proposed by Caves et al. (1982) that uses the average fir of the firm' size group as a reference point and then chain-links the reference points to preserve transitiveness. This extension takes into account the characteristics of the data set, in particular, the fact that sampling proportions are different for small and large firms A similar extension of the index can be found in Good et al. (1996). The main advantage of this kind of measure is that the parameters of the production function are not required to compute productivity.

The ESEE provides observations

$$
\left\{\left(Y_{f t}, W_{f t}^{k}, X_{f t}^{k}, k=1, \ldots, K\right), f=1, \ldots, N, t=1, \ldots, T\right\},
$$

where $Y_{f t}$ is the output level of the fir $f$ at time $t, W_{f t}^{k}$ and $X_{f t}^{k}$ are, respectively, the cost share and the quantity of input $k$ corresponding to fir $f$ at time $t$. The definitio of the three inputs considered (labor, materials and capital) and output can be found in Appendix A. Capital letters denote the number of firm $(N)$, the number of time periods $(T)$ and the number of inputs $(K)$. Firms are classifie in two size groups and $I$ different industries ${ }^{2}$. Let us introduce the dummy variables,

\footnotetext{
${ }^{2}$ Firms have been grouped in 18 industries corresponding to NACE-CLIO R-25 classification
} 


$$
\begin{aligned}
& s_{f \tau}=1(\text { firm } f \text { belongs to size group } \tau \text { ) } \\
& i_{f r}=1 \text { (firm } f \text { belongs to industry } r \text { ), }
\end{aligned}
$$

where $1(A)$ is the indicator function of event $A$. It is assumed that observations for different firms at a given period, are independent. It is also assumed that the distributions of the variables at different periods can be different, so we do not assume stationarity. The expression of total factor productivity index at time $t$, for the fir $f$, which belongs to the size group $\tau$ and to the industry $r$ is

$$
\begin{aligned}
\ln \lambda_{f t}= & \ln Y_{f t}-\overline{\ln Y}_{\tau r}-\frac{1}{2} \sum_{k=1}^{K}\left(W_{f t}^{k}+\bar{W}_{\tau r}^{k}\right)\left(\ln X_{f t}^{k}-\overline{\ln X}_{\tau r}^{k}\right) \\
& +\overline{\ln Y}_{\tau r}-\overline{\ln Y}_{r}-\frac{1}{2} \sum_{k=1}^{K}\left(\bar{W}_{\tau r}^{k}+\bar{W}_{r}^{k}\right)\left(\overline{\ln X}_{\tau r}^{k}-\overline{\ln X_{r}^{k}}\right),
\end{aligned}
$$

where, for notational convenience, we drop reference to the size group, $\tau$, and industry, $r$; and for a generic variable $a_{f t}$, which can be $\ln Y_{f t}, W_{f t}^{k}$ or $\ln X_{f t}^{k}$

$$
\bar{a}_{\tau r}=\frac{1}{N T} \sum_{f=1}^{N} \sum_{t=1}^{T} a_{f t} s_{f \tau} i_{f r} \quad \text { and } \quad \bar{a}_{r}=\frac{1}{N T} \sum_{f=1}^{N} \sum_{t=1}^{T} a_{f t} i_{f r} .
$$

This index measures the proportional difference of total factor productivity for fir $f$ at time $t$ relative to a given reference firm The reference fir varies across industries and, for a given industry $r$, it is define as the fir such that: (i) its output is equal to the geometric mean of firm output quantities in industry $r$ over the entire period; (ii) the quantities of inputs are equal to the geometric means of firm input quantities in industry $r$ over the entire period; and (iii) the cost shares of inputs are equal to the arithmetic mean of firm cost shares in industry $r$ over the entire period. Notice that the reference fir varies across industries and, therefore, when observations of different industries are pooled, productivity differences among industries are removed.

To clarify the meaning of the productivity index, we can interpret the terms on the right hand side separately. The firs set of terms compares the fir with the average fir of the same size group, which is taken as reference. Hence, comparisons between observations corresponding to the same size group are transitive. The second set of terms measures productivity differences between the reference fir of a size group and a common reference firm which is the average fir over the entire sample of firm in industry $r$. Thus, comparisons between observations corresponding to different size groups are also transitive. Consider, for example that fir $f$ belongs to industry $r$ and employs more than 200 workers. The firs set of terms gives the proportional difference of total factor productivity for fir $f$ at time $t$ with respect to the average fir in the group of large firm producing in industry $r$. The second set of terms, adds the proportional difference 
between the reference fir for the group of large firm in industry $r$ and the common reference fir for both size groups in this industry.

\subsection{Implementation of the tests}

In this section we discuss some issues related to the application of one and two-sided Kolmogorov-Smirnov tests to our data set. In particular, there are four questions that have to be considered.

First, the application of the testing procedure define in Section 2.2 requires independence of the observations. Given the panel structure of our sample of firms observations for different years correspond to firm that are repeated, and therefore cannot be considered either independent or stationary. Consequently, the application of Kolmogorov-Smirnov tests has to be done separately for each time period.

Second, testing for stochastic dominance requires the use of empirical distributions of the compared groups of firms Given the sampling properties of our data set, we use cumulative distribution functions for the two size categories (small and large firms ). Comparisons between distribution functions for the whole population are avoided since this would have required the estimation of a mixture of two distributions. Therefore, we compare different groups of firms i.e. exporters and non-exporters, within the same size category or between sizecategories (the productivity index preserves transitiveness along the two size categories).

Third, it should be notice that our productivity measure, $\ln \lambda_{f t}$, can be interpreted as an estimate of a non-observable measure, say $\ln \lambda_{f t}^{*}$, with sample averages replaced by population means. The Kolmogorov-Smirnov's test is directly applicable to $\ln \lambda_{f t}^{*}$. However, the limiting process of the sample distribution of $\ln \lambda_{f t}$, which contains estimated parameters, depends on certain unknown features of the data generating process, and the empirical distribution function converges to a non-pivotal process (see e.g. Durbin, 1973). Bai (1996) has shown that structural stability tests, which are a type of two-sample test, for distribution functions based on residuals of linear regression models are distribution free. Also, Delgado and Mora (2000) have shown that independence tests based on the difference between the joint distribution and the product of marginal distributions (Hoeffding-Blum-Kiefer-Rosenblatt test) are also distribution free when residuals, rather than observations, are employed. Despite the fact that this result has not been extended to two-sample problems for general functions depending non-linearly on estimated parameters, in a earlier version of this paper (see Delgado et al., 1999) we have proved formally that asymptotic KolmogorovSmirnov's tests is also distribution free. Therefore, we can use the same tables for the test based on $\ln \lambda_{f t}$ and the infeasible $\ln \lambda_{f t}^{*}$.

Fourth, we provide two $P$-values for each of the statistics: one based on the limiting distribution and the other on the bootstrap approximation. Asymptotic and 
bootstrap $P$-values are fairly close, which illustrates the good accuracy of the asymptotic approximation. The 'naive' bootstrap for empirical processes has been justifie by Giné and Zinn (1990). Bootstrap $P$-values are computed in our context as follows.

(a) Obtain a resample $\chi_{N}^{*}=\left\{z_{1}^{*}, \ldots, z_{n}^{*}, z_{n+1}^{*}, \ldots, z_{n+m}^{*}\right\}$ by random sampling with replacement from $\chi_{N}=\left\{z_{1}, \ldots, z_{n}, z_{n+1}, \ldots, z_{n+m}\right\}$.

(b) Compute bootstrap analogs of $\delta_{N}$ and $\eta_{N}$, say $\delta_{N}^{*}$ and $\eta_{N}^{*}$, based on the resample $\chi_{N}^{*}$.

The bootstrap $P$-values are

$$
\begin{aligned}
& P^{*} \text {-value }\left(\delta_{N}\right)=\operatorname{Pr}\left\{\delta_{N}^{*} \geq \delta_{N} \mid \chi_{N}\right\} \\
& P^{*} \text {-value }\left(\eta_{N}\right)=\operatorname{Pr}\left\{\eta_{N}^{*} \geq \eta_{N} \mid \chi_{N}\right\} .
\end{aligned}
$$

Calculating these $P$-values is computationally unapproachable in practice. However, they can be approximated, as accurately as desired, by Monte Carlo. That is, we repeat steps (a) and (b) $B$ times, $B$ as large as desired accuracy, obtaining bootstrap statistics $\delta_{N}^{* b}$ and $\eta_{N}^{*^{b}}, b=1, \ldots, B$. The bootstrap $P$-values are approximated by

$$
\begin{aligned}
& P_{B}^{*} \text {-value }\left(\delta_{N}\right)=\frac{1}{B} \sum_{b=1}^{B} 1\left(\delta_{N}^{* b} \geq \delta_{N}\right) \\
& P_{B}^{*} \text {-value }\left(\eta_{N}\right)=\frac{1}{B} \sum_{b=1}^{B} 1\left(\eta_{N}^{* b} \geq \eta_{N}\right) .
\end{aligned}
$$

Under $H_{1}$, the bootstrap $P$-values converge to zero almost surely.

To further illustrate the comparisons between different groups of firm we have graphed estimates of the distribution functions. In particular, we have computed the smooth, or perturbed, sample distribution function, rather than the sample distribution function itself, which provides nice smooth distribution estimates. The smooth sample distribution estimator was proposed by Nadaraya (1964). Since the purpose here is to produce graphical representations of the differences between two groups of firms we represent these distributions for the whole population of firms Consider for that purpose the distribution $F_{t}($.$) , which corresponds to the$ productivity of, say, exporting firms and $F_{t}\left(. \mid \tau=\tau_{0}\right), \tau_{0}=\{0,1\}$, which denotes the conditional distribution function for a given size group of firm - small $(\tau=0)$ or large $(\tau=1)$. The selective sampling scheme used in our data set implies that only these conditional cumulative distribution functions, $F_{t}\left(. \mid \tau=\tau_{0}\right)$, can be estimated directly. However, the cumulative distribution function for the whole population of exporters can be obtained by the following expression:

$$
F_{t}(.)=P_{t}(\tau=0) \times F_{t}(. \mid \tau=0)+P_{t}(\tau=1) \times F_{t}(. \mid \tau=1)
$$

where $P_{t}($.$) represents the probability of being either a small or a large fir in the$ considered group of exporting firms This expression indicates that the cumulative 
distribution function for the whole population of firm can be estimated as a weighted average of the two conditional cumulative distribution functions. Marginal probabilities can be calculated from the information provided by the $\mathrm{ESEE}^{3}$. For example, following this procedure, in Fig. 1 we report estimators of distribution functions for the whole population of firms which permits visual comparisons between any pair of distribution functions.

A different but related graphical tool is the relative distribution function, $R$. This distribution permits us to compare a target distribution, for example the distribution $G$, to a reference distribution $F$. This tool is an alternative that can be used to depict the two compared distributions directly as in Fig. 1. The relative

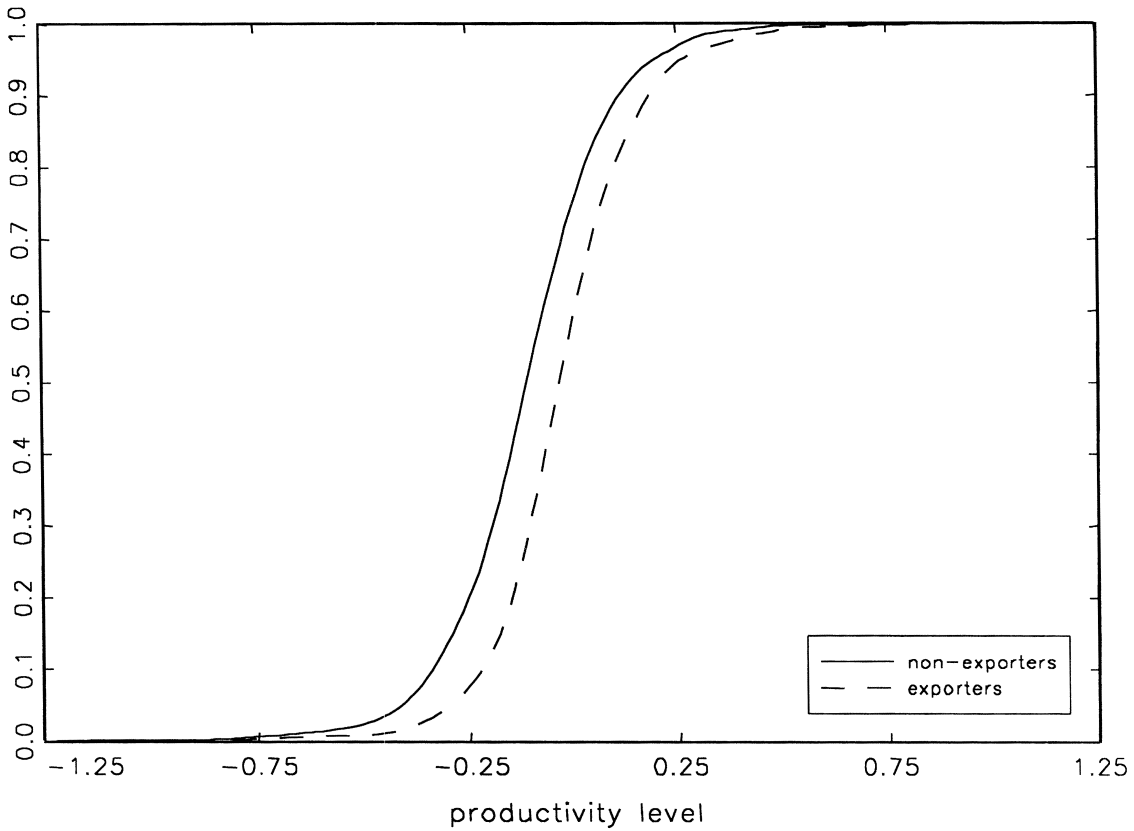

Fig. 1. Productivity differences of exporters versus non-exporters (smooth sample distribution function).

\footnotetext{
${ }^{3}$ The estimation of marginal probabilities for the population of firm takes into account the sampling proportions of the data set. As Section 3.1 indicates, the sampling proportion is 0.05 for small firm and 0.7 for large firms Therefore, for any group of firms say exporters, the number of large and small firm can be estimated multiplying the number of firm in the sample by the inverse of the sampling proportion. This procedure permits the calculation of relative frequencies and therefore the estimation of marginal probabilities of being either a small or a large firm In particular, for the group of non-exporting firms the estimated probability of being small is $\hat{P}_{t}(\tau=0)=0.993$ and the probability of being large is $\hat{P}_{t}(\tau=1)=0.007$. For the group of exporting firms these probabilities are $\hat{P}_{t}(\tau=0)=$ 0.924 and $\hat{P}_{t}(\tau=1)=0.076$.
} 


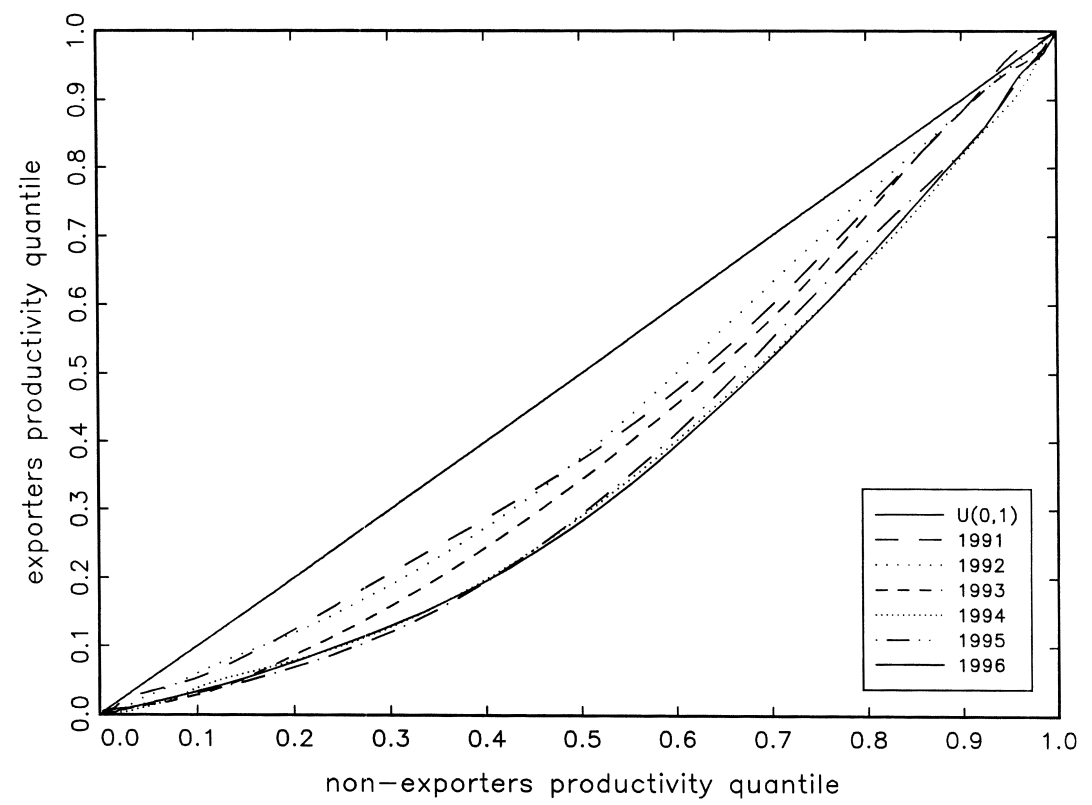

Fig. 2. Relative distribution functions of exporters' productivity to non-exporters' productivity: 1991-96.

distribution is define as $R(r)=G\left(F^{-1}(r)\right)$, where $0 \leq r \leq 1$. Notice that if both distributions are identical, then the relative distribution, i.e. $F\left(F^{-1}(r)\right)$, is the uniform distribution on [0,1]. Fig. 2 provides an example of the comparison between two distributions over several years. The diagonal represents the uniform distribution, i.e. the relative distribution if both distributions were identical. The position of the relative distribution below the diagonal suggests that the distribution represented in the vertical axis stochastically dominates the distribution in the horizontal axis.

The next section presents the results based on formal tests of the differences between various groups of firms Systematic visual representations of the compared distributions are also included.

\section{Empirical results}

This section is organized as follows. First, we begin by examining differences in total factor productivity between exporters and non-exporters. Second, we explore a possible source for the observed differences between exporting and nonexporting firm by examining if fir transitions between the domestic and the export market are consistent with certain patterns of productivity differences. We 
make two comparisons: (1) ex-ante productivity differentials between firm entering into the export market and non-exporters and (2) productivity differences between exiting exporters and continuing exporters. Finally, we examine whether or not productivity growth of firm in contact with the export market is greater than the productivity growth of non-exporters. All these comparisons are carried out through non-parametric methods described in previous sections.

\subsection{Exports and productivity}

We begin the analysis of the relationship between productivity and exports by examining the magnitude of productivity differentials between exporting firm and non-exporting firms Exporters are define as firm that export at period $t$, and non-exporters are firm not selling abroad at $t$; in both cases switchers are excluded. Very frequently, switchers are a special type of exporting fir that sells abroad intermittently, in time intervals greater than a year. For this reason, the group of firm switching their export status more than once during the given period are excluded from the comparison. However, results reported below do not change when switchers are included in accordance to their export status in year $t$.

Fig. 1 illustrates the differences between the productivity distributions of exporting and non-exporting firm in year 1996 within the whole population of firms The position of the distribution for exporting firm with respect to the distribution of non-exporting firm indicates higher levels of productivity for exporters versus non-exporters. All quartiles of the productivity distributions are higher for exporting firm relative to non-exporting firms In particular, the median productivity of the former is $7 \%$ higher than the productivity of the latter. Productivity differences are greater at the lower part of the distribution, $10 \%$ in favor of exporting firm at the lower quartile, and smaller in the upper part, $5 \%$ in favor of exporting firm at the upper quartile.

Fig. 2 shows the relative distribution of exporting firm with respect to non-exporting firm for all of the years in the period 1991-1996. The relative distribution is a graphical tool for the comparison of two distributions. As Fig. 2 illustrates, the position of the relative distribution of exporters to non-exporters is below the diagonal during the whole period; suggesting that the productivity distribution of exporters stochastically dominates the distribution of non-exporters. In 1996 around $50 \%$ of non-exporting firms productivity is below the $30 \%$ quartile of exporting firms productivity.

Given the assessed differences, now we formally test to see if the productivity distribution of exporting firm stochastically dominates the productivity distribution of non-exporting firm For each time period and size group $\tau_{0}$, we compare

$$
F_{t}\left(. \mid \tau=\tau_{0}\right) \quad \text { vs. } \quad G_{t}\left(. \mid \tau=\tau_{0}\right), t=1991, \ldots, 1996 \text { and } \tau_{0}=0,1
$$

using the one and two-sided tests described in Section 2.2, where $F_{t}$ and $G_{t}$ denote 
Table 1

Productivity level differences between exporters and non-exporters; hypotheses test statistics

\begin{tabular}{|c|c|c|c|c|c|c|c|c|c|c|c|}
\hline \multirow[t]{4}{*}{ Year } & \multicolumn{6}{|c|}{ Small exporting firm vs. small non-exporting firm } & \multicolumn{5}{|c|}{ Large exporting firm vs. large non-exporting firm } \\
\hline & \multicolumn{2}{|c|}{ Number of observations } & \multirow{2}{*}{\multicolumn{2}{|c|}{$\begin{array}{l}\text { Equality of } \\
\text { distributions }\end{array}$}} & \multirow{2}{*}{\multicolumn{2}{|c|}{$\begin{array}{l}\text { Differences favorable } \\
\text { to exporters }\end{array}$}} & \multicolumn{2}{|c|}{ Number of observations } & \multirow{2}{*}{\multicolumn{2}{|c|}{$\begin{array}{l}\text { Equality of } \\
\text { distributions }\end{array}$}} & \multirow{3}{*}{$\begin{array}{l}\text { Differences fas } \\
\text { to exporters } \\
\text { Statistic }\end{array}$} \\
\hline & \multirow[t]{2}{*}{ Exporters } & \multirow{2}{*}{$\begin{array}{l}\text { Non- } \\
\text { exporters }\end{array}$} & & & & & \multirow[t]{2}{*}{ Exporters } & \multirow{2}{*}{$\begin{array}{l}\text { Non- } \\
\text { exporters }\end{array}$} & & & \\
\hline & & & Statistic & $P$-value ${ }^{\mathrm{a}}$ & Statistic & $P$-value ${ }^{\mathrm{a}}$ & & & Statistic & $P$-value ${ }^{\mathrm{a}}$ & \\
\hline \multirow[t]{2}{*}{1991} & \multirow[t]{2}{*}{361} & \multirow[t]{2}{*}{725} & \multirow[t]{2}{*}{2.270} & 0.000 & 0.384 & 0.745 & \multirow[t]{2}{*}{598} & \multirow[t]{2}{*}{82} & \multirow[t]{2}{*}{0.956} & 0.320 & \multirow[t]{2}{*}{0.272} \\
\hline & & & & $(0.000)$ & & $(0.729)$ & & & & $(0.304)$ & \\
\hline \multirow[t]{2}{*}{1992} & \multirow[t]{2}{*}{373} & \multirow[t]{2}{*}{730} & \multirow[t]{2}{*}{2.152} & 0.000 & 0.088 & 0.985 & \multirow[t]{2}{*}{541} & \multirow[t]{2}{*}{63} & \multirow[t]{2}{*}{0.872} & 0.432 & \multirow[t]{2}{*}{0.872} \\
\hline & & & & $(0.000)$ & & $(0.975)$ & & & & $(0.373)$ & \\
\hline \multirow[t]{2}{*}{1993} & \multirow[t]{2}{*}{395} & \multirow[t]{2}{*}{673} & \multirow[t]{2}{*}{2.604} & 0.000 & 0.016 & 0.999 & \multirow[t]{2}{*}{457} & \multirow[t]{2}{*}{47} & 0.512 & 0.956 & 0.433 \\
\hline & & & & $(0.000)$ & & $(0.998)$ & & & & $(0.926)$ & \\
\hline 1994 & 428 & 606 & 3.544 & 0.000 & 0.000 & 1.000 & 510 & 48 & 0.750 & 0.627 & 0.357 \\
\hline & & & & $(0.000)$ & & $(1.000)$ & & & & $(0.577)$ & \\
\hline 1995 & 441 & 519 & 3.529 & 0.000 & 0.000 & 1.000 & 470 & 43 & 0.825 & 0.505 & 0.450 \\
\hline & & & & $(0.000)$ & & $(1.000)$ & & & & $(0.454)$ & \\
\hline 1996 & 477 & 537 & 3.771 & 0.000 & 0.030 & 0.998 & 447 & 37 & 0.615 & 0.843 & 0.454 \\
\hline & & & & $(0.000)$ & & $(0.997)$ & & & & $(0.777)$ & \\
\hline
\end{tabular}

${ }^{\text {a }} P$-values are based on the limiting distribution. $P$-values based on the bootstrap approximation (10 000 replications) are presented in parenthes 
the productivity level $\left(\ln \lambda_{f t}\right)$ distribution for exporting firm and non-exporting firm in year $t$, respectively.

Table 1 presents the hypotheses test statistics of productivity differentials between exporters and non-exporters. Tests are applied separately both to the groups of small and large firms First, for the group of small firms the null hypothesis of equality between both distributions can be rejected at the 0.01 level for all years. The null hypothesis that the sign of the difference is as expected, i.e. small exporters have greater productivity than small non-exporters, cannot be rejected at any reasonable significanc level. Second, for the groups of large exporters and non-exporters, the equality of both productivity distributions cannot be rejected at any reasonable significanc level. Although productivity differences between exporters and non-exporters are rather modest in the group of large firms they favor large exporters with respect to non-exporters, as suggested by test statistics reported in Table 1. $P$-values based both on the limiting distribution and on the bootstrap approximation lead to the same results.

Two conclusions can be derived from previous test statistics: (1) the productivity distribution of small exporting firm stochastically dominates the productivity distribution of small non-exporting firms and (2) the productivity distribution of large exporting firm is not above the productivity distribution of large nonexporting firms To obtain conclusions about productivity differences in the whole population of firms some additional comparison across size groups is required. In particular, the difference between exporters and non-exporters, $\left[F_{t}()-.G_{t}().\right]$, can be expressed as a linear combination of productivity differences in the group of small firm $\left[F_{t}(. \mid \tau=0)-G_{t}(. \mid \tau=0)\right]$, the group of large firm $\left[F_{t}(. \mid \tau=1)-\right.$ $\left.G_{t}(. \mid \tau=1)\right]$, and differences between large non-exporting firm and small nonexporting firm $\left[G_{t}(. \mid \tau=1)-G_{t}(. \mid \tau=0)\right]$. A formal test of this latter difference leads to the conclusion that the productivity distribution of large non-exporting firm stochastically dominates the distribution of small non-exporting firms Furthermore, the parameters weighting the linear combination are positive. Therefore, our results can also be interpreted as evidence supporting the hypothesis that in the whole population of firms exporters stochastically dominate non-exporters.

\subsection{Productivity and transitions between the domestic and the export market}

We turn now to the consideration of possible sources for productivity differences between exporting and non-exporting firms We explore whether or not the higher productivity of exporters reflect selection forces at work, i.e. export markets selecting the most efficien firms This selection mechanism can work both on the entry side and on the exit side. On the entry side, the implication of selection is that only firm with higher productivity should enter the export market. On the exit side, if selection is at work, low productivity exporters should leave the export market. 
To test for selection on the entry side of the export market, we compare two groups of firms non-exporters and entering exporters. To defin both groups we take as a reference the set of non-exporting firm in 1991. Entering exporters are define as the group of firm entering the export market at some point between 1992 and 1996. The rest of firm define the group of non-exporters. Switchers are excluded from the comparison. We consider a 5 year entry period that permits us to enlarge the number of observations. The test performed compares the productivity level of both groups of firm in the year 1991, before entry took place for the group of entering exporters.

For the whole population of firms Fig. 3 reports kernel estimators of the cumulative distribution functions of productivity for non-exporters and entering exporters. Both distributions correspond to the year 1991. The distribution position for entering firm is to the right of the position of non-exporters, indicating that firm that eventually enter the export market were more efficien than nonexporters. To examine this difference more formally, we test to see if the productivity level distribution of entering firm in the export market stochastically dominates the productivity distribution of non-exporters during the period before entry took place. Consequently, we apply the one and two-sided tests to compare

$$
F_{t}\left(. \mid \tau=\tau_{0}\right) \quad \text { vs. } \quad G_{t}\left(. \mid \tau=\tau_{0}\right), \quad t=1991 \text { and } \tau_{0}=0,1,
$$

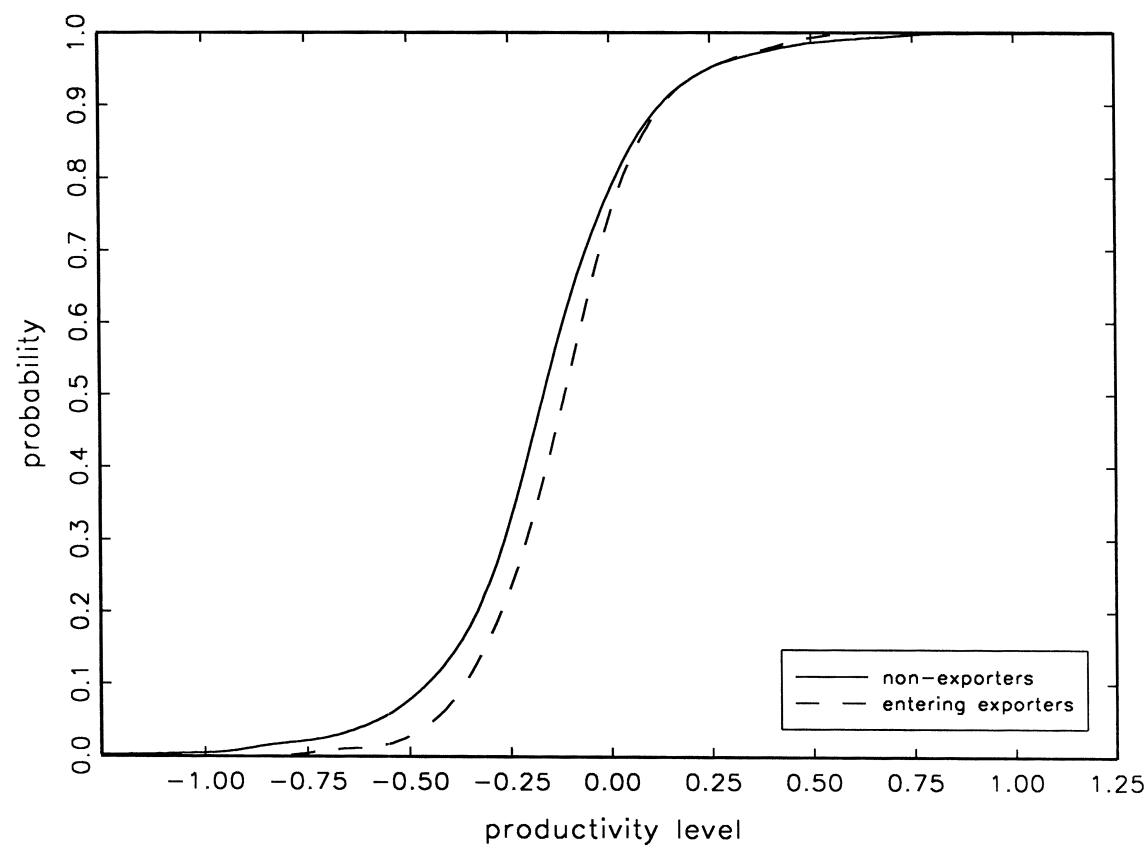

Fig. 3. Ex-ante productivity differences of entering exporters versus non-exporters: 1992-1996 cohort of entering firm (smooth sample distribution function). 
Table 2

Ex-ante productivity level differences between entering-exporters and non-exporters; hypotheses test statistics

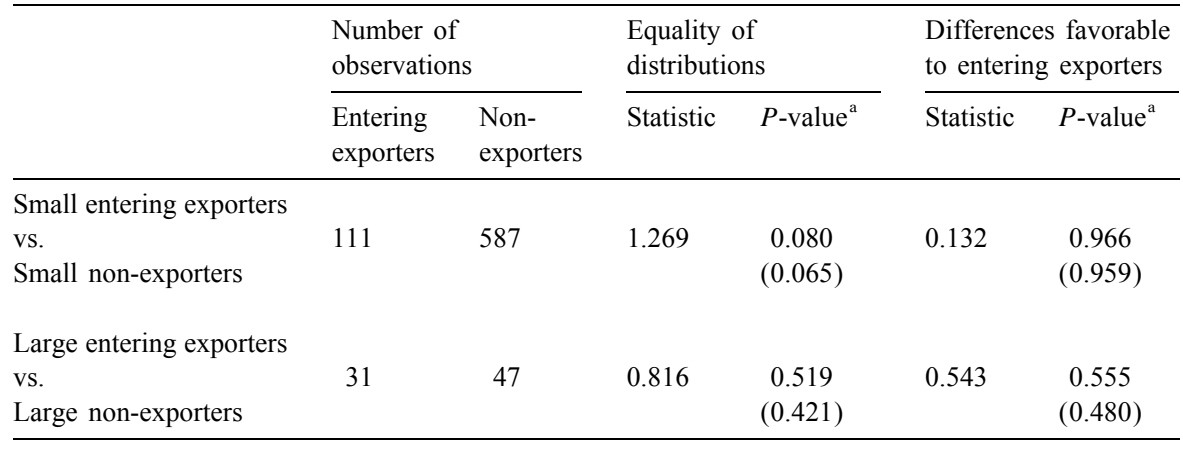

${ }^{a} P$-values are based on the limiting distribution. $P$-values based on the bootstrap approximation (10 000 replications) are included in parentheses.

where $F$ denotes the productivity level distribution of firm entering the export market and $G$ the distribution of non-exporters.

Table 2 reports test statistics on the comparison of both productivity distributions. First, in the group of small firm we are able to reject the null hypothesis of equality of distributions at the 0.10 significanc level in the year before entry. The null hypothesis that the difference favors to small entering exporters cannot be rejected at any reasonable significanc level. Second, for the group of large firm we are not able to reject the equality of productivity distributions between entering exporters and non-exporters at standard significanc levels. As in the case of exporting and non-exporting firms it can be proved that both results, together with the fact that large entering exporters dominate to small entering exporters, support the hypothesis of stochastic dominance of entering exporters versus to non-exporters for the whole population of large and small firms

Now we test for selection on the exit side. Fig. 4 reports estimators of the cumulative distribution functions of productivity for the 1995-96 cohort of exiting exporters and continuing exporters. The position of both distributions indicates that exiting exporters have lower productivity than exporters that remain in the market. To test for selection on the exit side of the export market, we compare the ex-ante productivity distribution of exiting exporters and exporters that remain active. Since only small exiting firm are observed, we restrict the comparison to small firms For the cohort $t / t+1, F$ denotes the productivity distribution in period $t$ of firm exiting the export market in period $t+1$ and $G$ the productivity distribution in period $t$ of continuing exporters, i.e. firm exporting at $t$ and $t+1$. In period $t$, we test to determine whether or not the ex-ante productivity distribution of continuing exporters stochastically dominates the productivity 


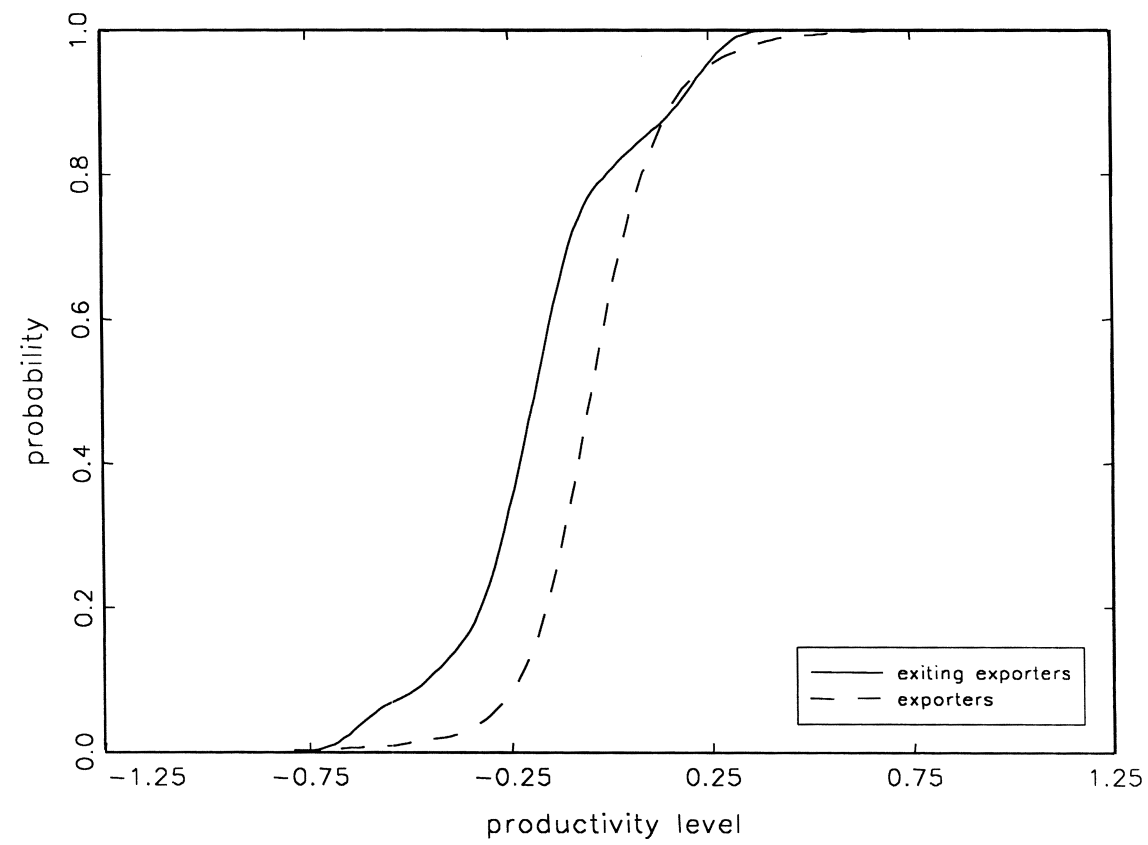

Fig. 4. Ex-ante productivity differences of exiting exporters versus continuing exporters: 1995-96 cohort of exiting firm (smooth sample distribution function).

distribution of exiting exporters. Therefore, the one and two-sided tests are applied to compare

$$
F_{t}\left(. \mid \tau=\tau_{0}\right) \quad \text { vs. } \quad G_{t}\left(. \mid \tau=\tau_{0}\right), \quad t=1991, \ldots, 1995 \text { and } \tau_{0}=0,1,
$$

Table 3 presents test statistics of productivity differences between both distributions. For the 1995-96 cohort we are able to reject the null hypothesis of equality of both distributions at the 0.01 level. The null hypothesis that the sign of the differential is as expected cannot be rejected at any reasonable significanc level. Similar conclusions are obtained for the 1992-1993 and 1994-95 cohorts of exiting and continuing exporters. For the cohorts of exiting exporters in years 1992 and 1994, we are not able to reject the hypothesis of equality of their ex-ante productivity distribution with respect to continuing exporters.

\subsection{Export markets and productivity growth}

A different perspective has been put forward to explain the positive relationship between exports and productivity. This view implies that entry in the export market provides the fir benefit that result in higher productivity. Consequently, 
Table 3

Ex-ante productivity level differences between exiting exporters and continuing exporters; hypotheses test statistics

\begin{tabular}{|c|c|c|c|c|c|c|}
\hline \multirow[t]{4}{*}{ Year } & \multicolumn{6}{|c|}{ Small exiting exporters vs. small continuing exporters } \\
\hline & \multicolumn{2}{|c|}{ Number of observations } & \multirow{2}{*}{\multicolumn{2}{|c|}{$\begin{array}{l}\text { Equality of } \\
\text { distributions }\end{array}$}} & \multirow{2}{*}{\multicolumn{2}{|c|}{$\begin{array}{l}\text { Differences favorable to } \\
\text { continuing exporters }\end{array}$}} \\
\hline & \multirow{2}{*}{ Exiting exporters } & \multirow{2}{*}{ Continuing exporters } & & & & \\
\hline & & & Statistic & $P$-value ${ }^{\mathrm{a}}$ & Statistic & $P$-value ${ }^{\mathrm{a}}$ \\
\hline $1991-1992$ & 19 & 329 & 0.917 & $\begin{array}{c}0.369 \\
(0.309)\end{array}$ & 0.917 & $\begin{array}{c}0.187 \\
(0.157)\end{array}$ \\
\hline $1992-1993$ & 21 & 345 & 1.490 & $\begin{array}{l}0.024 \\
(0.017)\end{array}$ & 0.000 & $\begin{array}{c}1.000 \\
(1.000)\end{array}$ \\
\hline $1993-1994$ & 10 & 386 & 0.532 & $\begin{array}{c}0.940 \\
(0.890)\end{array}$ & 0.404 & $\begin{array}{c}0.721 \\
(0.662)\end{array}$ \\
\hline $1994-1995$ & 12 & 417 & 1.177 & $\begin{array}{l}0.125 \\
(0.094)\end{array}$ & 0.000 & $\begin{array}{l}1.000 \\
(1.000)\end{array}$ \\
\hline $1995-1996$ & 14 & 434 & 1.765 & $\begin{array}{c}0.004 \\
(0.002)\end{array}$ & 0.229 & $\begin{array}{c}0.900 \\
(0.862)\end{array}$ \\
\hline
\end{tabular}

${ }^{\text {a }} P$-values are based on the limiting distribution. $P$-values based on the bootstrap approximation (10 000 replications) are included in parentheses.

the productivity gap between firm that enter and those that do not enter the export market should increase after entry. This behavior may be associated to learning (for example, the knowledge that exporters acquire in international markets), although the exact channels that generate differences in productivity growth are difficul to establish.

To test this view we examine whether or not productivity growth for firm in contact with the export market is greater than productivity growth for nonexporters. Again, let $F$ denote the distribution that corresponds to exporting firm during the period 1991-96 and $G$ the distribution of firm that never exported during the same period of time. We compare the distributions of productivity growth between both groups of firm during the period 1991-1996,

$$
F_{t}\left(. \mid \tau=\tau_{0}\right) \quad \text { vs. } \quad G_{t}\left(. \mid \tau=\tau_{0}\right), \quad t=1996 \text { and } \tau_{0}=0,1,
$$

where firm-leve productivity growth between years $t-k$ and $t$ is given by $\ln$ $\lambda_{f t}-\ln \lambda_{f t-k}$.

Table 4 reports test statistics that indicate that we cannot reject the equality of both productivity growth distributions for the groups of small and large firms The sign of the differential favors to exporters only in the group of small firms Overall, we cannot reject the equality of both distributions at the standard significanc level, and therefore the evidence in favor of learning is not conclusive.

The structure of the data set permits us to design alternative ways of testing the learning-by-exporting hypothesis. In particular, for firm accumulating experience 
Table 4

Productivity growth differences between exporters and non-exporters: all firms hypotheses test statistics

\begin{tabular}{|c|c|c|c|c|c|c|}
\hline & \multicolumn{2}{|c|}{ Number of observations } & \multicolumn{2}{|c|}{$\begin{array}{l}\text { Equality of } \\
\text { distributions }\end{array}$} & \multicolumn{2}{|c|}{$\begin{array}{l}\text { Differences favorable to } \\
\text { entering exporters }\end{array}$} \\
\hline & Exporters & $\begin{array}{l}\text { Non- } \\
\text { exporters }\end{array}$ & Statistic & $P$-value $^{\mathrm{a}}$ & Statistic & $P$-value ${ }^{\mathrm{a}}$ \\
\hline $\begin{array}{l}\text { Small exporters } \\
\text { vs. } \\
\text { Small non-exporters }\end{array}$ & 491 & 341 & 0.997 & $\begin{array}{c}0.274 \\
(0.250)\end{array}$ & 0.097 & $\begin{array}{c}0.981 \\
(0.970)\end{array}$ \\
\hline $\begin{array}{l}\text { Large exporters } \\
\text { vs. } \\
\text { Large non-exporters }\end{array}$ & 437 & 16 & 0.925 & $\begin{array}{c}0.359 \\
(0.302)\end{array}$ & 0925 & $\begin{array}{c}0.181 \\
(0.155)\end{array}$ \\
\hline
\end{tabular}

\footnotetext{
${ }^{\text {a }} P$-values are based on the limiting distribution. $P$-values based on the bootstrap approximation (10 000 replications) are included in parentheses.
}

in the export market, if learning occurs, we will observe a divergence in productivity levels between entering exporters and non-exporting firms Similarly, yet in the opposite direction, we will also observe a convergence between the productivity levels of entering exporters and exporting firms The hypothesis of divergence between the productivity level distributions of new exporters and non-exporting firm can be examined by testing for stochastic dominance of the productivity growth distribution of entering exporters with respect to non-exporters. Similar comparisons can be made to examine convergence between entering exporters and continuing exporters.

To test for divergence between new exporters and non-exporters, we examine whether or not productivity growth for firm entering the export market is greater than productivity growth for non-exporters. Let $F_{t}$ denote the productivity growth distribution that corresponds to the cohort of firm entering the export market in year $t$, and $G_{t}$ the distribution of non-exporters. Two cohorts of firm are considered: that of entering exporters in the year 1991 and that of entering exporters in 1992. For both groups of firm and for non-exporters, productivity growth refers to periods 1991-1996 and 1992-1996, respectively. Therefore, we compare

$$
F_{t}\left(. \mid \tau=\tau_{0}\right) \quad \text { vs. } \quad G_{t}\left(. \mid \tau=\tau_{0}\right), \quad t=1991,1992 \text { and } \tau_{0}=0,1 .
$$

In the upper panel of Table 5 we report test statistics corresponding to the comparison of the productivity growth of entering exporters and non-exporters. For both small and large firms results indicate that we cannot reject the equality of both distributions, and therefore there is no evidence of divergence between the two groups of firms

In the lower panel of Table 5 a similar comparison is performed for entering 
Table 5

\begin{tabular}{|c|c|c|c|c|c|c|c|c|c|c|c|}
\hline \multirow[t]{4}{*}{ Cohort } & \multicolumn{6}{|c|}{ Small entering exporters vs. small non-exporters } & \multicolumn{5}{|c|}{ Large entering-exporters vs. large non-exporters } \\
\hline & \multicolumn{2}{|c|}{ Number of observations } & \multirow{2}{*}{\multicolumn{2}{|c|}{$\begin{array}{l}\text { Equality of } \\
\text { distributions }\end{array}$}} & \multirow{2}{*}{\multicolumn{2}{|c|}{$\begin{array}{l}\text { Differences favorable } \\
\text { to entering-exporters }\end{array}$}} & \multicolumn{2}{|c|}{ Number of observations } & \multirow{2}{*}{\multicolumn{2}{|c|}{$\begin{array}{l}\text { Equality of } \\
\text { distributions }\end{array}$}} & \multirow{3}{*}{$\begin{array}{l}\text { Differences fav } \\
\text { to exporters } \\
\text { Statistic }\end{array}$} \\
\hline & \multirow{2}{*}{$\begin{array}{l}\text { Entering } \\
\text { exporters }\end{array}$} & \multirow{2}{*}{$\begin{array}{l}\text { Non- } \\
\text { exporters }\end{array}$} & & & & & \multirow{2}{*}{$\begin{array}{l}\text { Entering } \\
\text { exporters }\end{array}$} & \multirow{2}{*}{$\begin{array}{l}\text { Non- } \\
\text { exporters }\end{array}$} & & & \\
\hline & & & Statistic & $P$-value ${ }^{\mathrm{a}}$ & Statistic & $P$-value $^{\mathrm{a}}$ & & & Statistic & $P$-value ${ }^{\mathrm{a}}$ & \\
\hline \multirow[t]{2}{*}{1991} & \multirow[t]{2}{*}{15} & \multirow[t]{2}{*}{330} & \multirow[t]{2}{*}{0.953} & 0.324 & \multirow[t]{2}{*}{0.149} & 0.956 & \multirow[t]{2}{*}{11} & \multirow[t]{2}{*}{27} & \multirow[t]{2}{*}{0.537} & 0.936 & \multirow[t]{2}{*}{0.424} \\
\hline & & & & $(0.260)$ & & $(0.927)$ & & & & $(0.826)$ & \\
\hline \multirow[t]{2}{*}{1992} & \multirow[t]{2}{*}{12} & \multirow[t]{2}{*}{374} & \multirow[t]{2}{*}{0.767} & 0.598 & \multirow[t]{2}{*}{0.767} & 0.308 & \multirow[t]{2}{*}{9} & \multirow[t]{2}{*}{22} & \multirow[t]{2}{*}{0.600} & 0.864 & \multirow[t]{2}{*}{0.600} \\
\hline & & & & $(0.521)$ & & $(0.274)$ & & & & $(0.682)$ & \\
\hline \multicolumn{12}{|c|}{ (b) Productivity growth* differences between entering-exporters and continuing-exporters } \\
\hline \multirow[t]{4}{*}{ Cohort } & \multicolumn{6}{|c|}{ Small entering exporters vs. small continuing-exporters } & \multicolumn{5}{|c|}{ Large entering-exporters vs. large continuing-exporters } \\
\hline & Number o & vations & Equality & & Differenc & rable & Number of & vations & Equality & & Differences favi \\
\hline & Entering & Continuing & distributi & & to enterin & & Entering & Continuing & distributic & & to exporters \\
\hline & exporters & exporters & Statistic & $P$-value $^{\mathrm{a}}$ & Statistic & $P$-value ${ }^{\mathrm{a}}$ & exporters & exporters & Statistic & $P$-value ${ }^{\mathrm{a}}$ & Statistic \\
\hline 1991 & 15 & 203 & 0.862 & 0.448 & 0.228 & 0.901 & 11 & 409 & 0.636 & 0.814 & 0.636 \\
\hline & & & & $(0.375)$ & & $(0.845)$ & & & & $(0.727)$ & \\
\hline 1992 & 12 & 223 & 0.985 & 0.287 & 0.985 & 0.144 & 9 & 379 & 1.038 & 0.232 & 1.038 \\
\hline & & & & $(0.221)$ & & $(0.108)$ & & & & $(0.200)$ & \\
\hline
\end{tabular}

* Productivity growth corresponds to period 1991-96 for the cohort of 1991 and to period 1992-1996 for the cohort of 1992.

${ }^{a} P$-values are based on the limiting distribution. $P$-values based on the bootstrap approximation (10 000 replications) are presented in parenthes 
exporters with respect to continuing exporters. The cohorts of entering firm in the export market in 1991 and 1992 are now compared with the group of exporters. We are not able to reject the null hypothesis of equality of both distributions and as a result the evidence in favor of learning is not conclusive in this case either.

A possible explanation for not rejecting the equality of previous distributions may be that we are comparing heterogeneous firm with regard to their learning processes. In order to control this heterogeneity we repeat the testing procedure, restricting the sample to firm which are 5 or less years old at the beginning of the period 1991-1996. By doing this we are assuming that learning effects are more intensive for this group of firms In fact, we are comparing productivity growth for two groups of firms young entering exporters and young entering domestic firm with no contact with the export market. The age constraint we impose when definin both groups implies that we restrict our attention to the evolution of productivity in two rather homogeneous groups of firm from the point of view of their age and market life cycle. We compare the distributions of productivity growth during the period 1991-96. We only observe young non-exporters in the group of small firms and therefore the comparison between the distribution of non-exporters and the distribution of either small and large exporters, are sufficien conditions to test for stochastic dominance in the whole population of firms Then, we compare

$$
F_{t}\left(. \mid \tau=\tau_{0}\right) \quad \text { vs. } \quad G_{t}\left(. \mid \tau=\tau_{0}\right), \quad t=1996 \text { and } \tau_{0}=0,1 .
$$

Table 6 reports the results on test statistics corresponding to both groups of firms Now, we are able to reject the null hypothesis of equality of both distributions at the 0.05 significanc level. Furthermore, we cannot reject the

Table 6

Productivity growth differences between young entering exporters and young entering domestic firms age $\leq 5$ years old; hypotheses test statistics

\begin{tabular}{|c|c|c|c|c|c|c|}
\hline & \multicolumn{2}{|c|}{$\begin{array}{l}\text { Number of } \\
\text { observations }\end{array}$} & \multicolumn{2}{|c|}{$\begin{array}{l}\text { Equality of } \\
\text { distributions }\end{array}$} & \multicolumn{2}{|c|}{$\begin{array}{l}\text { Differences favorable } \\
\text { to entering exporters }\end{array}$} \\
\hline & Exporters & $\begin{array}{l}\text { Non- } \\
\text { exporters }\end{array}$ & Statistic & $P$-value & Statistic & $P$-value \\
\hline $\begin{array}{l}\text { Small exporters } \\
\text { vs. } \\
\text { Small non-exporters }\end{array}$ & 69 & 71 & 1.317 & $\begin{array}{c}0.062 \\
(0.045)\end{array}$ & 0.348 & $\begin{array}{c}0.785 \\
(0.717)\end{array}$ \\
\hline $\begin{array}{l}\text { Large exporters } \\
\text { vs. } \\
\text { Small non-exporters }\end{array}$ & 37 & 71 & 1.496 & $\begin{array}{c}0.023 \\
(0.017)\end{array}$ & 0.006 & $\begin{array}{l}1.000 \\
(0.986)\end{array}$ \\
\hline
\end{tabular}

$P$-values are based on the limiting distribution. $P$-values based on the bootstrap approximation (10 000 approximations) are included in parentheses. 


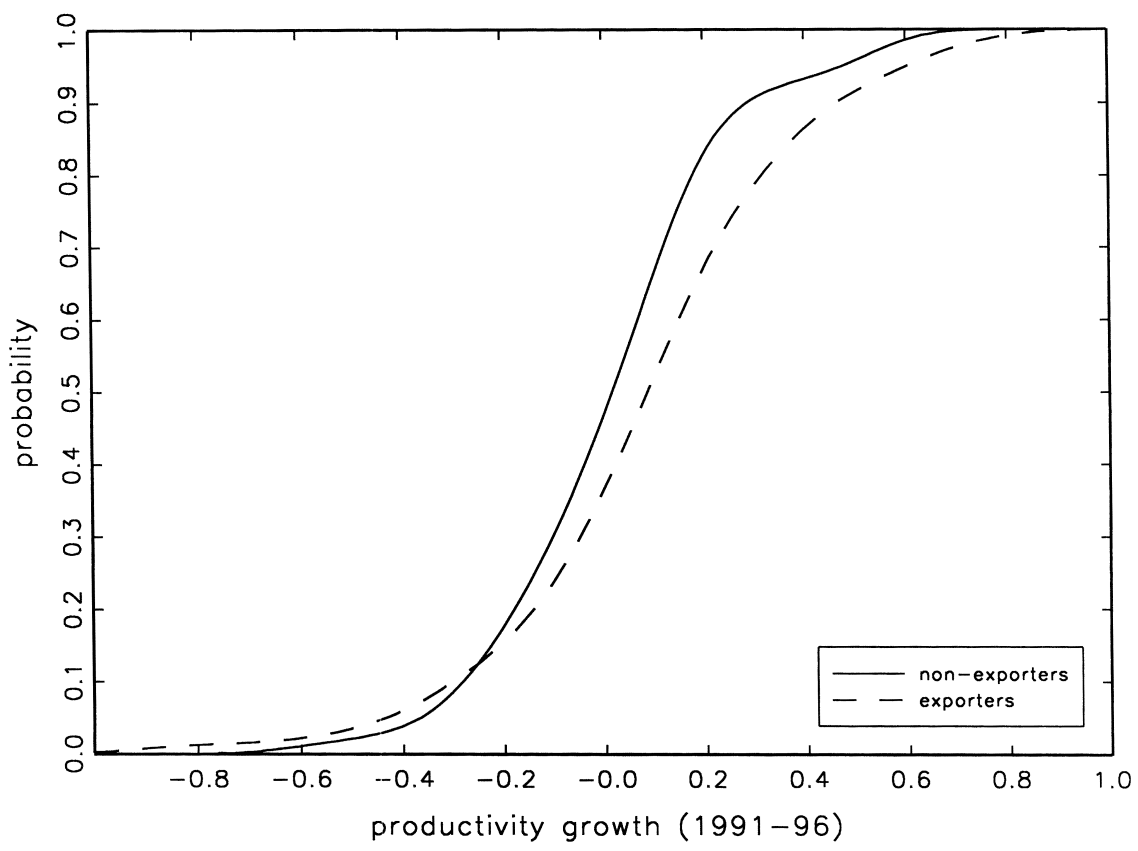

Fig. 5. Productivity growth differences of young entering exporters versus young entering domestic firms age $\leq 5$ years old (smooth sample distribution function).

null-hypothesis that productivity growth is greater for young entering exporters (either small or large) with respect to young non-exporters. Fig. 5 reports the cumulative distribution estimates for productivity growth of exporters and nonexporters; in both cases firm are 5 or less years old at the beginning of the period. The position of the distribution of exporters is to the right of that of non-exporters, except for the lower tail of the distribution.

\section{Conclusions}

This paper has examined total factor productivity differences between exporting and non-exporting firms These differences are examined using a sample of Spanish manufacturing firm over the period 1991-1996 drawn from the ESEE. The paper also examines two complementary explanations for the greater productivity of exporting firms (1) the market selection hypothesis, and (2) the learning hypothesis. Our empirical strategy is to compare productivity distributions of groups of firm with different transition patterns between the export and the domestic market. To organize the analysis we rely on models of fir and industry dynamics. Our results can be summarized as follows: 
First, our data suggests clearly higher levels of productivity for exporting firm versus non-exporters.

Productivity differences observed in the data are consistent with the argument of self-selection of more efficien firm into the export market. First, on the entry side of the market we fin evidence in favor of selection. Firms that eventually enter the export market had higher productivity than non-exporters in the period prior to their entry. Second, on the exit side of the export market we also fin evidence which favors to selection. The ex-ante productivity distribution of continuing exporters stochastically dominates the productivity distribution of exiting exporters.

Finally, although the evidence we present in favor of self-selection is compelling, our results are less conclusive with respect to the learning-by-exporting hypothesis. During the period, productivity growth is similar for exporters and non-exporters and therefore evidence in favor of the learning hypothesis is not conclusive for the whole sample of firms The comparison of entering exporters with respect to either continuing exporters or non-exporters generates similar results. We do not fin significan differences between the productivity growth distribution of entering exporters and the distribution of continuing exporters, in the period after entry, and similarly for entering exporters versus non-exporters. The fact that we are not able to reject the null hypothesis of equality between these productivity growth distributions indicates that the evidence in favor of learning is not conclusive in both cases either. However, by restricting the sample of firm to the group of younger ones, for which learning effects are stronger, we fin some evidence in support of this hypothesis. Post-entry productivity growth is greater for young exporters than for young domestic firm which are not active exporters. For these groups of young firm we fin that initial differences in the productivity level increase after entry.

\section{Acknowledgements}

We are grateful to José M. Campa, Ricardo Cao, Rebeca de Juan, Ana Martí n, Daniel Miles, Mark J. Roberts, José M. Vidal and Gretchen Dobrott for their useful comments on previous versions of the paper. We have also benefite from suggestions from the editor, Robert C. Feenstra, and from anonymous referees. Earlier versions of this paper were presented in Torino (EARIE Conference), Valencia (Jornadas Economí a Internacional), Madrid (Jornadas Economí a Industrial) and Oviedo. This research has been partially funded by projects SEC971368 and DGES PB98-0025.

\section{Appendix A}

The multilateral total factor productivity index for each fir is computed using a 
Spanish manufacturing firms data set drawn from the Encuesta sobre Estrategias Empresariales (ESEE). The variables needed for the index are define as follows:

Output: measured by annual gross production of goods and services expressed in real terms using individual price indexes for each fir drawn from the ESEE.

Labor input: measured by the number of effective yearly hours of work, which is equal to normal yearly hours plus overtime yearly hours minus non-working yearly hours.

Materials: measured by the cost of intermediate inputs; which includes raw material purchases, energy and fuel costs and other services paid for by the firm This concept is expressed in real terms using individual price indexes of intermediate inputs for each fir drawn from the ESEE.

Capital stock: is calculated following the perpetual inventory formula:

$$
k_{t}^{*}=I_{t}+k_{t-1}^{*}\left(1-d_{t}\right) \frac{P_{t}}{P_{t-1}}
$$

where $I_{t}$ represents investment in equipment, $d_{t}$ stands for depreciation rates and $P_{t}$ corresponds to price indexes for equipment published by the Instituto Nacional de Estadí stica.

Input cost shares: For each input, the cost share is the fraction of the cost of the input on total input costs, where the total cost is the sum of the cost of labor, the cost of intermediate inputs and the cost of capital. The cost of labor is measured by the sum of wages, social security contributions, and other labor costs paid for by the firm The cost of capital is calculated with an estimation of the user cost of capital, which is measured by the cost of long-term external debt of the fir plus depreciation rates $\left(d_{t}\right)$ minus the variation of the price index for capital goods.

\section{References}

Aw, B.Y., Hwang, A., 1995. Productivity and the export market: A firm-leve analysis. Journal of Development Economics 47, 313-332.

Aw, B.Y., Chen, X., Roberts, M.J., 1997. Firm level evidence on productivity differentials, turnover, and exports in Taiwanese manufacturing. NBER Working Paper 6235.

Aw, B.Y., Chung, S., Roberts, M.J., 2000. Productivity and turnover in the export market: Micro evidence from Taiwan and South Korea. The World Bank Economic Review 14 (1), 65-90.

Bai, J., 1996. Testing for parameter constancy in linear regressions: an empirical distribution function approach. Econometrica 64 (3), 597-622.

Bernard, A.B., Jensen, J.B., 1995. Exporters, jobs and wages in U.S. manufacturing, 1976-1987. The Brooking papers on economic activity. Microeconomics 1995, 67-112.

Bernard, A., Jensen, J.B., 1999. Exceptional exporter performance: cause, effect or both? Journal of International Economics 47, 1-25.

Campa, J.M., 1998. Hysteresis in trade: how big are the numbers?. Working Paper 9802, Programa de Investigaciones Económicas, Fundación Empresa Pública.

Caves, D.W., Christensen, L.R., Diewert, E., 1982. Multilateral comparisons of output, input, and productivity using superlative index numbers. The Economic Journal 92, 73-86. 
Clerides, S.K., Lach, S., Tybout, J.R., 1998. Is learning-by-exporting important? Micro-dynamic evidence from Colombia, Mexico and Morocco. Quarterly Journal of Economics CXIII, 903-947.

Darling, D.A., 1957. The Kolmogorov-Smirnov, Cramér-Von Mises tests. Annals of Mathematical Statistics 28, 823-838.

Delgado, M.A., Fariñas, J.C., Ruano, S., 1999. Firm's productivity and the export market: a non-parametric approach. Working Paper 9903, Programa de Investigaciones Económicas, Fundación Empresa Pública.

Delgado, M.A., Mora, J., 2000. A non-parametric test for serial independence of regression errors. Biometrika 87, 228-234.

Durbin, J., 1973. Weak convergence of the sample distribution function when parameters are estimated. Annals of Statistics 1, 279-290.

Ericson, R., Pakes, A., 1995. Markov-perfect industry dynamics: A framework for empirical work. Review of Economic Studies 62, 53-82.

Feenstra, R., 1997. In: Handbook of International Economics. Estimating the effects of trade policy, Vol. III. Elsevier Science B.V.

Giné, E., Zinn, J., 1990. Bootstrapping general empirical measures. Annals of Probability 18, 851-869.

Good, D., Nadiri, M.I., Sickles, R., 1996. Index number and factor demand approaches to the estimation of productivity. NBER Working Paper 5790.

Griliches, Z., Regev, H., 1995. Firm productivity in Israeli industry 1979-1988. Journal of Econometrics $65,75-203$.

Hopenhayn, H., 1992. Entry, Exit, and fir dynamics in long run equilibrium. Econometrica 60, $1127-1150$.

Jensen, J.B., Wagner, J., 1997. Exports and success in German manufacturing. Weltwirtschaftliches Archiv 133 (1), 134-157.

Jovanovic, B., 1982. Selection and the evolution of industry. Econometrica 50, 649-670.

Kolmogorov, A.N., 1933. Sulla determinazione empirica di une legge didistribuzione. Giornale dell Istituto Ital. degli Attuari 4, 83-91.

Ministry of Industry (1992). Un Panorama de la Industria Española, Madrid.

Nadaraya, E.A., 1964. Some new estimates for distribution functions. Theory of Probability and its Applications 9, 497-500.

Smirnov, N.V., 1939. On the estimation of the discrepancy between empirical curves of distribution for two independent samples. Bull. Math. Univ. Moscow 2, 3-14.

Tybout, J.R., 1997. Heterogeneity and productivity growth: assessing the evidence. In: Roberts, M.J., Tybout, J.R. (Eds.), Industrial Evolution in Developing Countries. Oxford University Press.

Roberts, M.J., Tybout, J.R., 1997. The decision to export in Colombia: An empirical model of entry with sunk costs. American Economic Review 87 (4), 545-564. 